\title{
Holocene hydrological changes in the Rhône River (NW Mediterranean) as recorded in the marine mud belt
}

\author{
Maria-Angela Bassetti ${ }^{1}$, Serge Berné ${ }^{1}$, Marie-Alexandrine Sicre $^{2}$, Bernard Dennielou ${ }^{3}$, Yoann Alonso ${ }^{1}$, \\ Roselyne Buscail $^{1}$, Bassem Jalali ${ }^{4}$, Bertil Hebert ${ }^{1}$, and Christophe Menniti ${ }^{1}$ \\ ${ }^{1}$ CEFREM UMR5110 CNRS, Université de Perpignan Via Domitia, Perpignan, France \\ ${ }^{2}$ Sorbonne Universités (UPMC, Université Paris 06)-CNRS-IRD-MNHN, LOCEAN Laboratory, \\ 4 place Jussieu, 75005 Paris, France \\ ${ }^{3}$ IFREMER, Centre de Brest, Plouzané, France \\ ${ }^{4}$ GEOGLOB, Université de Sfax, Sfax, Tunisia
}

Correspondence to: Maria-Angela Bassetti (maria-angela.bassetti@univ-perp.fr)

Received: 17 January 2016 - Published in Clim. Past Discuss.: 25 February 2016

Accepted: 18 June 2016 - Published: 15 July 2016

\begin{abstract}
Expanded marine Holocene archives are relatively scarce in the Mediterranean Sea because most of the sediments were trapped in catchment areas during this period. Mud belts are the most suitable targets to access expanded Holocene records. These sedimentary bodies represent excellent archives for the study of sea-land interactions and notably the impact of the hydrological activity on sediment accumulation. We retrieved a $7.2 \mathrm{~m}$ long sediment core from the Rhône mud belt in the Gulf of Lions in an area where the average accumulation rate is ca. $0.70 \mathrm{~m} 1000 \mathrm{yr}^{-1}$. This core thus provides a continuous and high-resolution record of the last $10 \mathrm{ka}$ cal BP. A multiproxy dataset (XRF core scan, ${ }^{14} \mathrm{C}$ dates, grain size and organic-matter analysis) combined with seismic stratigraphic analysis was used to document decadal to centennial changes in the Rhône hydrological activity. Our results show that (1) the early Holocene was characterized by high sediment delivery likely indicative of local intense (but short-duration) rainfall events, (2) important sediment delivery around $7 \mathrm{kacal} \mathrm{BP}$ presumably related to increased river flux, (3) a progressive increase in continental/marine input during the mid-Holocene despite increased distance from river outlets due to sea-level rise possibly related to higher atmospheric humidity caused by the southward migration of the storm tracks in the North Atlantic, (4) multidecadal to centennial humid events took place in the late Holocene. Some of these events correspond to the cold periods identified in the North Atlantic (Little Ice Age, LIA; Dark Ages Cold Period) and also coincide with time intervals of major
\end{abstract}

floods in the northern Alps. Other humid events are also observed during relatively warm periods (Roman Humid Period and Medieval Climate Anomaly).

\section{Introduction}

The Holocene climate is characterized by centennial-scale climate changes that punctuated the final deglacial warming after the Younger Dryas. Renssen et al. (2009), Rogerson et al. (2011) and Wanner et al. (2008, 2014) provided an extensive review of Holocene climate variability mainly based on chronologically well-constrained continental temperature time series that emphasize the superimposition of the insolation-driven climate changes with those induced by other external forcings such as solar activity, volcanism and greenhouse gases $\left(\mathrm{CH}_{4}, \mathrm{CO}_{2}\right.$ and $\left.\mathrm{NO}_{2}\right)$. Based on existing data, Holocene climate can be divided into four periods:

a. the early Holocene (between 11.7 and $8.2 \mathrm{kacalBP}$; Walker et al., 2012), characterized by a progressive warming-inducing ice cap melting and outbreaks of freshwater from North America glacial lakes, leading to a regional cooling in the Northern Hemisphere, i.e. the $8.2 \mathrm{ka}$ cal BP cold event (Barber et al., 1999);

b. the warm middle Holocene (between 8.2 and 4.2 ka cal BP; Walker et al., 2012) that coincides approximately with the Holocene thermal maximum 
(HTM) and is punctuated by several cold relapses (CRs) (Wanner et al., 2011). Events at 6.4, 5.3 and $4.2 \mathrm{kacalBP}$ are the most significant in terms of temperature change (Wanner et al., 2011). The $4.2 \mathrm{ka}$ event corresponds to enhanced dryness in the southern Mediterranean, Asia and North America that presumably played a role in the collapse of various civilizations (Magny et al., 2013).

c. the cold late Holocene (from $4.2 \mathrm{ka}$ cal BP to the mid 19th century; Walker et al., 2012), which includes the $2.8 \mathrm{ka}$ cal BP cold event possibly responsible for the collapse of the Late Bronze Age civilization (Do Carmo and Sanguinetti, 1999; Weiss, 1982) and the Migration Period cooling around $1.4 \mathrm{ka}$ cal BP (Wanner et al., 2014); the late Holocene cooling trend culminated during the Little Ice Age (LIA) between the 14th and 19th century (Wanner et al., 2011);

d. the warm industrial era from $1850 \mathrm{AD}$ onwards (Rogerson et al., 2011; Wanner et al., 2011).

In contrast to these cool events, the Medieval Climate Anomaly (MCA, 800-1300 AD) is often described as a warm period characterized by intense dryness in some regions of the Northern Hemisphere, such as for example Europe and the Mediterranean region, although it is not synchronous worldwide (PAGES-2k-Consortium, 2013).

The causes of Holocene climate variability are not yet fully understood despite recent advances achieved through the study of climate archives from all around the word from both marine and continental settings. There are still open questions: to what extent are these well-known climate events global rather than regional and what are the driving mechanisms at play? Numerical modeling allows examining in more detail and on a broader geographical scale causes of rapid climate changes and the role of natural or anthropogenic forcings by better integrating data from marine, land and ice archives. Nonetheless, there are significant discrepancies between proxy reconstructions and numerical simulations that suggest the need to generate better chronologically constrained high-resolution proxy records from continental and marine archives and develop new approaches (Anchukaitis and Tierney, 2013; Evans et al., 2013). Of particular interest are the locations that allow developing paleohydrological and paleoenvironmental investigations at the land-sea interface to better link atmospheric circulation controlling the precipitation pattern over the continent and changes in the thermohaline circulation.

Sediment drifts fed by water streams connected to the deep sea such as the Var (Bonneau et al., 2014) or mid-shelf mud belts are interesting locations to recover sedimentary archives where both continental and marine proxies can be analyzed. Mid-shelf mud belts, in particular, are depot centers fed by streams that result from various processes including diffusion under the influence of storms, advection by cur- rents and transport by gravity flows (Hill et al., 2007). They often form elongated sediment bodies, at between 10-30 and 60-100 m water depth, roughly parallel to the coastline. Such sediment bodies can reach several tens of meters in thickness when they are associated with large streams and form infralittoral prograding prisms (sometimes called subaqueous deltas) as for instance along the Italian Adriatic coast (Cattaneo et al., 2003). In some ways, they are shallow-water equivalents to contourites, but they generally display higher accumulation rates, making them ideal targets for paleoenvironmental reconstructions.

In this study, we present a continuous record of the Holocene climate obtained from a $7.03 \mathrm{~m}$ long sediment core retrieved from the Rhône mud belt in the Gulf of Lions. Owing to the high sedimentation rate of this environmental setting, we were able to generate sedimentological data on a decadal-scale resolution for sediment grain size and semiquantitative chemical composition obtained by means of continuous X-ray fluorescence. Organic-matter parameters and the overall seismic architecture of the mud belt were also used to reconstruct the terrigenous flux and the degree of alteration of land-derived material for investigating the relationship between detritic fluxes and the paleohydrology of peri-Mediterranean rivers. Based on the comparison of available data, we explored the linkages between rapid climate changes and continental paleohydrology with a focus on the Rhône River flood activity.

\section{Environmental and climatic framework}

\subsection{The Gulf of Lions geological and oceanographic settings}

The Gulf of Lions (GoL) is a passive and prograding continental margin with a relatively constant subsidence and a high sediment supply (Berné and Gorini, 2005). Located in the northwest sector of the Mediterranean Sea, the GoL is bounded to the west and to the east by the Pyrenean and Alpine orogenic belts, and comprises a crescent-shaped continental shelf with a maximum width of $72 \mathrm{~km}$ near the mouth of the Rhône (Berné et al., 2004). The general oceanic circulation is dominated by the geostrophic Liguro-Provençal or Northern Current (Millot, 1990), which is the northern branch of the general cyclonic circulation in the western Mediterranean basin. This current flows southwestward along the continental slope and intrudes on the continental shelf during northwesterly winds events (Millot, 1990; Petrenko, 2003). Surface water circulation in the GoL shelf is wind-dependent (Millot, 1990). Different wind patterns affect the circulation and transport of suspended particles on the shelf and produce distinctive wave regimes. The continental cold and dry winds known as the mistral and tramontane, blowing from the $\mathrm{N}$ and NW through the passages between the Pyrenees, the Massif Central and the Alps, are associated with a short fetch that generates small waves on the 
inner shelf. During winter, these winds induce strong cooling and mixing of the shelf waters, triggering dense-water formation (Estournel et al., 2003) and locally generating upwelling (Millot, 1990). Episodic and brief E-SE (marin or maritime regime) winds are associated with a long fetch and large swells. This wind regime induces a rise in sea level along the shore and intense cyclonic circulation on the shelf (Ulses et al., 2008), producing alongshore currents and downwelling (Monaco et al., 1990). Transport of humid marine air masses over the coastal relief induces abundant precipitation often accompanied by river flooding.

The main source of sediment in the GoL is the Rhône River (Pont et al., 2002) and to a lesser extent small rivers of the Languedoc-Roussillon region (Hérault, Orb, Aude, Agly, Têt, Tech) (Fig. 1). The latter experience episodic discharges (flash floods in spring and fall) that are difficult to quantify. The terrigenous sediment supply originating from the Rhône River represents $80 \%$ of the total sediment deposited on the shelf (Aloisi et al., 1977). The Rhône River drains a largely mountainous catchment area of $97800 \mathrm{~km}^{2}$, incising a geologically heterogeneous substrate, consisting of siliciclastic and carbonate sedimentary rocks in valley infills and a crystalline (plutonic and metamorphic from the Alpine domain) bedrock. The mean annual water discharge measured at the Beaucaire gauging station, downstream of the last confluence, is $1701 \mathrm{~m}^{3} \mathrm{~s}^{-1}$ (mean for 1961-1996); the solid discharge varies between 2 and $20 \times 10^{6}$ tons $_{\mathrm{yr}^{-1}}$ (Eyrolle et al., 2012; Pont et al., 2002).

Most of the sediment delivered by the Rhône is trapped on the inner shelf, mainly in prodeltas (Fanget et al., 2013; Ulses et al., 2008), but redistribution processes operating along the shelf create mid-shelf depocenters of fine sediments. The sediment accumulation rate varies from 20 to $50 \mathrm{~cm} \mathrm{yr}^{-1}$ at the present Roustan mouth of the Rhône River and strongly decreases with the distance from the river. Sediment is exported seaward by several turbid layers: the surface nepheloid layer, related to river plume; an intermediate nepheloid layer that forms during periods of water-column stratification; and a persistent bottom nepheloid layer, whose influence decreases from the river mouth to the outer shelf (Calmet and Fernandez, 1990; Naudin et al., 1997). The surficial plume is typically a few meters thick close to the mouth but rapidly thins seaward to a few centimeters (Millot, 1990); it is deflected southwestward by the surface water circulation on the GoL shelf. The predominance of the Rhône River in the sediment supply and the continental shelf circulation allow the identification of several zones in the GoL (Durrieu De Madron et al., 2000): (i) the deltaic and prodeltaic sediment units where most of the sediments are trapped, (ii) the mid-shelf mud belt between 20 and 50-90 m depth resulting from sediment transport under the influence of the main cyclonic westward circulation, and (iii) the outer shelf where fine-grained sedimentation is presently very low and where relict fine sands are episodically reworked during extreme meteorological events (Bassetti et al., 2006).

\subsection{Holocene paleohydrology in the western Mediterranean}

The hydrological budget in the Mediterranean borderlands depends on the seasonality of precipitation as well as the catchment geology, vegetation type and geomorphology of the region. In northwestern Mediterranean the most important fluvial discharges occur in spring and autumn, while minimum flow is observed in summer (Thornes et al., 2009). On a Holocene timescale, the Mediterranean fluvial hydrology is characterized by the alternation of wet and dry episodes related to changes in atmospheric circulation leading to a north-south hydrological contrast in the Mediterranean region with climate reversal occurring at about $40^{\circ} \mathrm{N}$ (Magny et al., 2013). Complex climate regimes result from external forcing (orbital, solar activity, volcanism) as well as from internal modes of atmospheric variability such as the North Atlantic Oscillation, east Atlantic, east-Atlantic-westRussian or Scandinavian modes (Josey et al., 2011; Magny et al., 2013).

In the NW Mediterranean, the Holocene fluvial hydrology has been reconstructed using major hydrological events (extreme floods and lake levels) recorded in lake and fluvial sediments (Arnaud et al., 2012; Benito et al., 2015; Magny et al., 2013; Wirth et al., 2013). Overall, the early Holocene climate was generally dry except for short pulses of higher fluvial activity reported in the Durance and southern Alps rivers (Arnaud-Fassetta et al., 2010). A marked cooling trend is observed with a major change around 7500 a cal BP (Fletcher and Sánchez Goñi, 2008) corresponding to humid conditions in the Iberian peninsula (Benito et al., 2015). The mid-Holocene (from ca. 7000 to 5000 a cal BP) also records low torrential activity but increasing flood frequency between 6000 and 4500 a cal BP in Spain, Tunisia and southern France (Arnaud-Fassetta, 2004; Benito et al., 2003; Faust et al., 2004), which evolves in the late Holocene to a general increase in fluvial activity, at least in the Rhône Basin catchment and north Alps domain (Wirth et al., 2013). In addition, anthropogenic activities (agriculture and deforestation) over the last 5000 years have modified the erosional rate in the catchment area, resulting in increased/decreased sediment delivery to the sea depending on the deforestation/forestation phases related to the agricultural development (Arnaud-Fassetta et al., 2000; van der Leeuw, 2005).

\subsection{Deglacial and Holocene history of the Rhône Delta}

During the last ca. $20 \mathrm{kyr}$, the morphology of the Rhône Delta strongly evolved in response to sea-level and climate changes. At the end of the Last Glacial Maximum, the Rhône reached the shelf edge and directly fed the Petit Rhône Canyon (Fig. 1) (Lombo Tombo et al., 2015). The disconnection between the river and the canyon head is dated to $19 \mathrm{kacal} \mathrm{BP}$ in response to rapid sea-level rise (Lombo Tombo et al., 2015). The landward retreat path of 


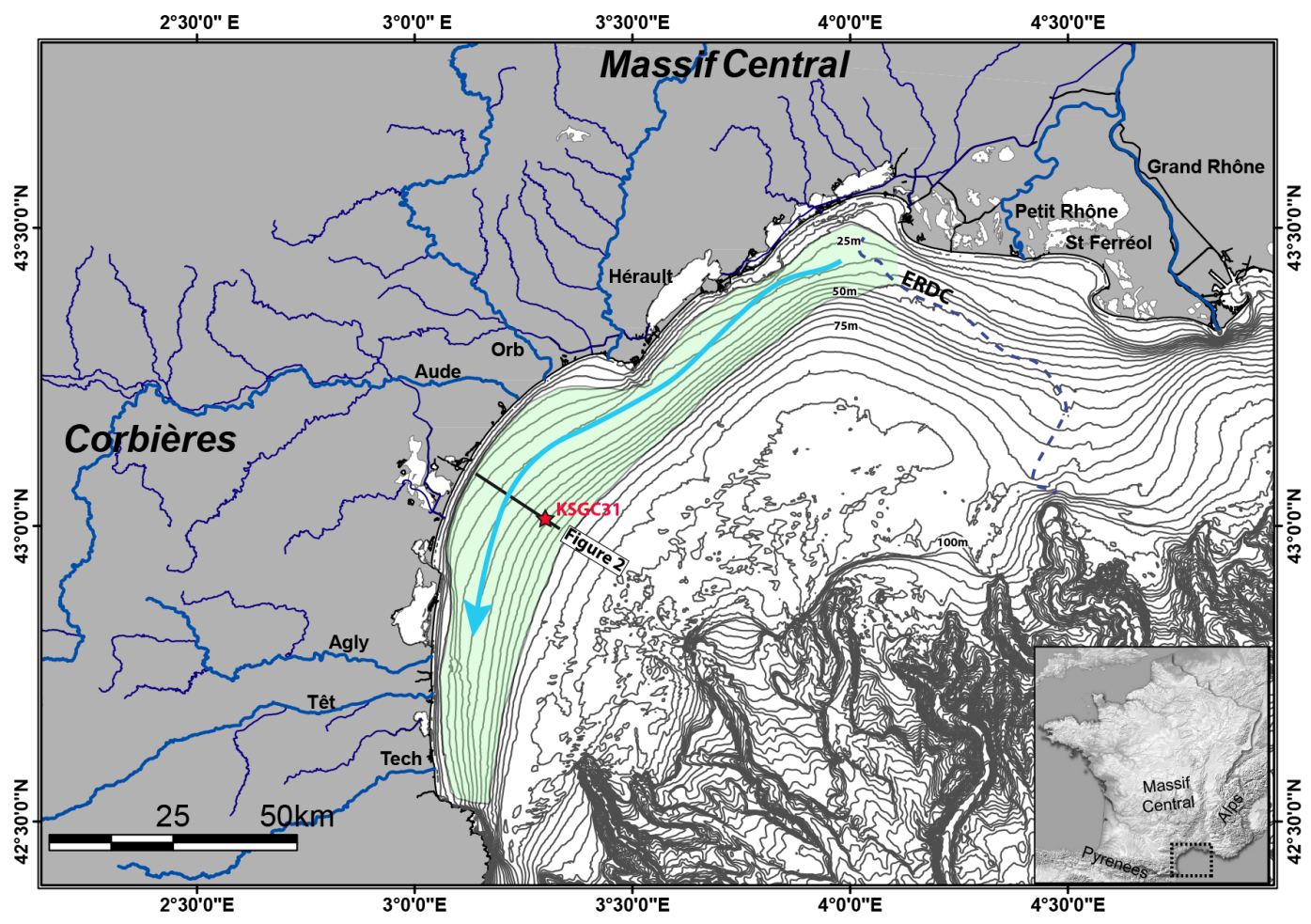

Figure 1. Bathymetric map of the Gulf of Lions and position of core KSGC31. The approximate extent of the Rhône mud belt is represented in green; the arrow represents the direction of dominant transport of suspended sediments. Bathymetric map based on Berné et al. (2007). Contour lines every $5 \mathrm{~m}$ on the shelf. The dotted line corresponds to the retreat path of the Rhône during the deglacial period (based on Gensous and Tesson, 2003; Berné et al., 2007; Jouet, 2007; Fanget et al., 2014; Lombo Tombo et al., 2015). ERDC: Early Rhône Deltaic Complex.

the estuary mouth on the shelf has been tracked through the mapping and dating of paleodelta lobes (Berné et al., 2007; Fanget et al., 2014; Gensous and Tesson, 2003; Jouet, 2007; Lombo Tombo et al., 2015) and, onshore, through the study of ancestral beach ridges (Arnaud-Fassetta, 1998; L'Homer et al., 1981; Vella and Provansal, 2000). During the Younger Dryas, an "Early Rhône Deltaic Complex" (ERDC) formed at depths between -50 and $-40 \mathrm{~m}$ below the present sea level (Berné et al., 2007). The estuary then shifted to the NW as the sea level rose during the early Holocene (Fanget et al., 2014). The period of maximum flooding in the delta (the turnaround between coastal retrogradation and coastal progradation) is dated to ca. 85007500 a cal BP (Arnaud-Fassetta, 1998). Around this time, the mouth of the Rhône was situated about $15 \mathrm{~km}$ north of its present position. Between this period and the Roman Age (approximately $20 \mathrm{BC}-390 \mathrm{AD}$ in western Europe), the position of the Rhône outlet(s) are not precisely known and many distributaries, with their associated deltaic lobes, have been identified. However, there is a general consensus on the eastward migration of the delta from the St Ferréol Distributary, which occupied the position of the modern Petit Rhône between ca. 6000 and 2500 a cal BP, and the modern Grand Rhône, rearranged for navigation at the end of the 19th cen- tury. To the west of the Rhône, a mud belt and subaqueous delta, about $150 \mathrm{~km}$ in length and up to $20 \mathrm{~m}$ thick, is observed (Fig. 1). So far, little attention has been paid to this sediment body, and neither seismic data nor detailed core analysis were available.

\section{Material and methods}

The gravity core KSGC-31 (7.03 m long) was retrieved from the Rhône mud belt $\left(43^{\circ} 0^{\prime} 23^{\prime \prime} \mathrm{N}, 3^{\circ} 17^{\prime} 56^{\prime \prime} \mathrm{E}\right.$; water depth $60 \mathrm{~m}$ ) during the GM02-Carnac cruise in 2002 on the R/V Le Suroitt. Seismic data were acquired in 2015 aboard R/V Néréis during the Madho1 cruise, using an $\mathrm{SIG}^{\mathrm{TM}}$ sparker. The shooting rate was $1 \mathrm{~s}$. Data were loaded on a Kingdom ${ }^{\mathrm{TM}}$ workstation. An average seismic velocity of $1550 \mathrm{~m} \mathrm{~s}^{-1}$ (based on measurements of sonic velocity with a Geotek ${ }^{\mathrm{TM}}$ core logger) was used to position the core data on seismic profiles. The uncertainty in the position of time lines on the seismic profile at the core position is on the order of $\pm 0.5 \mathrm{~m}$, taking into account the resolution of the seismic source, the errors in positioning and sound velocity calculation. Due to the shallow water depth, core deformation by cable stretching is considered negligible. 
Grain size analyses were carried out by mean of a Malvern ${ }^{\mathrm{TM}}$ Mastersize 3000 laser diffraction particle size analyzer using a HydroEV dispersing module, which measures particle grain sizes between 0.04 and $3000 \mu \mathrm{m}$. Samples were dispersed in a solution of $\left(\mathrm{NaPO}_{3}\right)_{6}\left(1.5 \mathrm{~g} \mathrm{~L}^{-1}\right.$ of distilled water) for $1 \mathrm{~h}$ in order to better disaggregate the sediment. Before each measurement, the sample was stirred on a rotating mixer for $20 \mathrm{~min}$. Grain size parameters were measured all along the core every centimeter. Three size ranges were used to classify the grains: clay $(<8 \mu \mathrm{m}$, as recommended by Konert and Vandenberghe (1997), coarse silt ( $>8$ and $<63 \mu \mathrm{m})$ and sand (>63 and $<250 \mu \mathrm{m})$. The D50, representing the maximum diameter of $50 \%$ of the sediment sample, was calculated.

Core KSGC31 was analyzed using an Avaatech XRF core scanner at IFREMER (Brest, France). This nondestructive method provides semiquantitative analyses of major and minor elements by scanning split sediment cores (Richter et al., 2006). Measurements were performed every $1 \mathrm{~cm}$ with a counting time of $20 \mathrm{~s}$ and a 10 and $30 \mathrm{kV}$ acceleration intensity. Resulting element abundances are expressed as elementto-element ratio. Three ratios are used in this work:

1. $\mathrm{Ca} / \mathrm{Ti}$ ratio, to account for two end-members in the sediment composition. The Ca is supposedly mostly derived from biogenic carbonates, while $\mathrm{Ti}$ is commonly used for tracking terrigenous sediments, even if usually found in small amounts. Nonetheless, it is worthwhile remembering that calcite of detritic origin, generated by erosion of calcareous massifs in the catchment area, represents an important component of the fluvial Rhône water sediment. This type of calcite is transported into the sea, but it is mainly accumulated in the sand fraction, trapped in the proximal deltaic sediments. In the mud belt, where deposits are mostly pelitic, the detritic calcite quickly decreases seaward of the river mouth, with only a very small fraction being preserved in the clay fraction (Chamley, 1971). On the other hand, calcite of biogenic marine origin (bioclasts) is usually abundant. Benthic (rare planktonic) foraminifera, ostracods, fragmented mollusk shells and debris from bryozoan and echinoids can be observed under the binocular microscope. Thus, the Ca content in the core KSGC31 is considered to be related to biogenic marine productivity.

2. $\mathrm{Zr} / \mathrm{Rb}$ reflects changes in grain size, with higher values in the relatively coarse-grained sediments. $\mathrm{Zr}$ is enriched in heavy minerals and commonly associated with the relatively coarse-grained (silt-sand) sediment fraction (highest $\mathrm{Zr}$ values are found in sandstones), whereas $\mathrm{Rb}$ is associated with the fine-grained fraction, including clay minerals and micas (Dypvik and Harris, 2001).

3. $\mathrm{K} / \mathrm{Ti}$ values can be related to illite content. Illite is formed by the weathering of K-feldspars under sub- aerial conditions, and most of the $\mathrm{K}$ leached from the rocks is adsorbed by the clay minerals and organic material before it reaches the ocean (Weaver, 1967). In the case of the GoL, the Rhône waters deliver mainly illite and chlorite to the Mediterranean Sea, whereas rivers flowing from Massif Central, Corbières and Pyrenees mainly carry illite and montmorillonite (Chamley, 1971). Thus, illite (K) is thought to be abundant in fluvial waters ending in the GoL, and thus $\mathrm{K}$ relative abundances can be used as a proxy for sediment continental provenance. Because illite may be depleted in $\mathrm{K}$ upon pedogenetic processes, the $\mathrm{K} / \mathrm{Ti}$ ratio can be considered an indirect proxy for the intensity of chemical weathering (Arnaud et al., 2012).

The XRF raw data were smoothed using a five-point moving average to remove background noise. In addition, semiquantitative bulk geochemical parameters such as total carbon (TC), organic carbon (OC) and total nitrogen (TN) were determined from freezed-dried homogenized and precisely weighed subsamples of sediment using the Elementar Vario MAX CN automatic elemental analyzer. Prior to the OC analyses, samples were acidified with $2 \mathrm{M} \mathrm{HCl}$ overnight at $50{ }^{\circ} \mathrm{C}$ in order to remove carbonates (Cauwet et al., 1990). The precision of TC, OC and TN measurements was 5 and $10 \%$. The calcium carbonate content of the sediments was calculated from $\mathrm{TC}-\mathrm{OC}$ using the molecular mass ratio $\left(\mathrm{CaCO}_{3}: \mathrm{C}=100: 12\right)$. Results are expressed as the weight percent of dry sediment ( $\%$ d.w.). The atomic $\mathrm{C}: \mathrm{N}$ ratio $\left(\mathrm{C}: \mathrm{N}_{\mathrm{a}}\right)$ was calculated and used as a qualitative descriptor of organic matter (OM). Moloney and Field (1991) proposed $\mathrm{C}: \mathrm{N}_{\mathrm{a}}=6$ for OM of marine origin because of the high protein content of organisms such as phytoplankton and zooplankton. Higher plant-derived OM of terrestrial origin have higher $\mathrm{C}: \mathrm{N}_{\mathrm{a}}$ ratios $(>20)$ than marine organisms because of a high percentage of non-protein constituents (Meyers and Ishiwatari, 1993). In marine sediment, $C: \mathrm{N}_{\mathrm{a}}$ ratios are usually higher than phytoplankton. $\mathrm{C}: \mathrm{N}_{\mathrm{a}}$ ratios between 6 and 10 are indicative of degraded organic detritus resulting from the breakdown of the more labile nitrogenous compounds, and values of $C: \mathrm{N}_{\mathrm{a}}$ ratio $>13$ indicate a significant contribution of terrestrial organic matter (Goñi et al., 2003).

The age model is based on 21 radiocarbon dates (Table 2) obtained by an accelerator mass spectrometer (AMS) at the Laboratoire de Mesure du Carbone 14, Saclay (France). The two uppermost dates were obtained at the Beta Analytic Radiocarbon Dating Laboratory and indicate postbomb values (AD 1950). The ${ }^{14} \mathrm{C}$ dates were converted into $1 \sigma$ calendar years using Calib7.1 (Stuiver and Reimer, 1993) and the MARINE 13 calibration dataset including the global marine reservoir age (400 years) (Charmasson et al., 1998). We used a local marine reservoir age correction of $\Delta R=23 \pm 71$ years (http://calib.qub.ac.uk/marine/ regioncalc.php). The age model was obtained by polynomial interpolation between ${ }^{14} \mathrm{C}$ dates excluding the minor rever- 
Table 1. Chronology of Holocene cold relapses (CRs) based on existing literature.

\begin{tabular}{lll}
\hline Event & Time slice (ka) & References \\
\hline CR0 & 8.2 & Barber et al. (1999) \\
CR1 & $6.4-6.2$ & Wanner et al. (2011) \\
CR2 & $5.3-5.0$ & $\begin{array}{l}\text { Magny and Haas (2004), } \\
\end{array}$ \\
CR3 & $4.2-3.9$ & Roberts et al. (2011) \\
CR4 & $2.8-3.1$ & Walker et al. (2012) \\
& & Chambers et al. (2007), \\
CR5 & $1.45-1.65$ & Swindles et al. (2007) \\
CR6 & $0.55-0.15$ & Wanner et al. (2011) \\
\hline
\end{tabular}

sal at $18.5 \mathrm{~cm}(350 \pm 78$ years $)$ and the two post-bomb dates. Timing and uncertainty for the main events is estimated using the Bayesian approach of OxCal 4.2 (Ramsey and Lee, 2013) (Table 3). We used the same age model as in Jalali et al. (2016). Age inversions are not used in the estimation of the sedimentation rate (SR) (Table 2).

\section{Results}

\subsection{Age model and sedimentological core description}

Core KSGC31 was retrieved at the seaward edge of the Rhône mud belt. The seismic profile at the position of the core displays the architecture of this mud belt that drapes Pliocene rocks and continental deposits of the Last Glacial Maximum (Fig. 2). The bottom of the core corresponds to the ravinement surface (RS in Fig. 2) that was formed by wave erosion at the time of marine flooding during the deglacial period. This $20 \mathrm{~cm}$ thick heterolytic interval includes fluvial and coastal sands and gravels mixed with marine shells in a muddy matrix. At the position of core KSGC31, it is postdated by the overlying muds immediately above (ca. 10000 a cal BP). The period of "turn around" between coastal retrogradation and coastal progradation is well marked on the seismic profile by a downlap surface dated to ca. $7.5 \mathrm{ka}$ cal BP at the position of the core. It corresponds to the maximum flooding surface in the sense of Posamantier and Allen (1999). Two other distinct seismic surfaces (higher amplitude, slightly erosional) can be recognized in the upper part of the wedge (Fig. 2); they are dated to ca. 4.2 and $2.5 \mathrm{ka}$ cal BP from the core.

Based on the $21{ }^{14} \mathrm{C}$ dates, the average SR has been es-

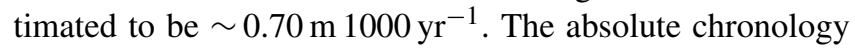
allows identifying three stratigraphic intervals corresponding to the formal subdivision of the Holocene epoch proposed by Walker et al. (2012). The well-known cold events (CRs) are defined on the basis of this chronology (Fig. 3, Table 1) and used in this paper to highlight possible correlation with local conditions.
The core is predominantly composed of silt (60-70\%) and clay. The clay content is highly variable but no more than $50 \%$ between 10000 and 4000 a cal BP and between 50 and $60 \%$ in its upper $350 \mathrm{~cm}$, corresponding to the last 4000 years (Fig. 3). Small-size shell debris is randomly mixed with the clayey silt but becomes more abundant between 400 and $500 \mathrm{~cm}$ depth. Abundant and well-preserved Turritella sp. shells that have certainly not been reworked are found between 680 and $640 \mathrm{~cm}$. The sand fraction is generally very low $(0.5-5 \%)$ except for the lowermost $30 \mathrm{~cm}$ (50\%, Fig. 3). At visual inspection, the thin sandy base (between 703 and $690 \mathrm{~cm}$ ) contains very abundant shell debris. Weak bioturbation is visible on the $\mathrm{X}$-ray images as well as the occurrence of sparse articulated shells.

\subsection{Elemental and geochemical distribution}

$\mathrm{Ca} / \mathrm{Ti}, \mathrm{K} / \mathrm{Ti}$ and $\mathrm{Zr} / \mathrm{Rb}$ ratios were generated and crossanalyzed with grain size (clay content D50 computed curve) and $\mathrm{C}: \mathrm{N}_{\mathrm{a}}$ to assess changes in geochemical composition.

In the early Holocene, the $\mathrm{Ca} / \mathrm{Ti}$ ratio is fairly constant and relatively high. The carbonate content is high ( $>45 \%$ $\mathrm{CaCO}_{3}$; Fig. 4b), whereas $\mathrm{C}: \mathrm{N}_{\mathrm{a}}$ values fluctuate greatly between values of $20(\sim 10 \mathrm{ka})$ and lower values of 13 towards the mid-Holocene (Fig. 4a). $\mathrm{Zr} / \mathrm{Rb}$ ratios gradually decrease, while $\mathrm{K} / \mathrm{Ti}$ shows relatively stable behavior. Between 7000 and $9000 \mathrm{acal} \mathrm{BP}, \mathrm{K} / \mathrm{Ti}$ and $\mathrm{Zr} / \mathrm{Rb}$ indicate lower values, but with a peak in the mid-interval, around $8200-8300$ a cal BP (Fig. 4d, e). Throughout the period, clay content is approximately between 24 and $52 \%$ (Fig. 5c); D50 is generally $>10 \mu \mathrm{m}$ and variable (Fig. 4f). A significant drop in $\mathrm{Ca} / \mathrm{Ti}$ and D50 is observed in the 7000-6400 a cal BP interval (Fig. 4c, f). Similar trends are observed for the K / Ti and $\mathrm{Zr} / \mathrm{Rb}$, but the most abrupt drop occurs between 6500 and $6400 \mathrm{a}$ cal BP. No significant changes are detected in the main lithology (mostly clayey; Fig. 3). C : $\mathrm{N}_{\mathrm{a}}$ ratios decrease $(<13)$ due to a better preservation of nitrogen in clay deposits.

After $6.4 \mathrm{kacal} \mathrm{BP}, \mathrm{Ca} / \mathrm{Ti}$ displays a constant decreasing trend until $4200 \mathrm{acal} \mathrm{BP}$. On the other hand, $\mathrm{C}: \mathrm{N}_{\mathrm{a}}$ between 6400 and 4200 a cal BP reveals two prominent peaks (>15) culminating at 5700 and $4800 \mathrm{acal} \mathrm{BP}$ (Fig. 4a) that roughly correspond to low $\mathrm{K} / \mathrm{Ti}$ and $\mathrm{Zr} / \mathrm{Rb}$ values (Fig. $4 \mathrm{~d}$, e) and higher clay (Fig. 5c) and lower carbonate sediment contents (Fig. 4b). The most pronounced changes in the elemental ratio are observed after 4200 a cal BP (Figs. 4 and 5). Millennial-scale oscillations are discernible in the $\mathrm{Ca} / \mathrm{Ti}$ record (Fig. 4c) and coherent with changes in $\mathrm{K} / \mathrm{Ti}$ and $\mathrm{Zr} / \mathrm{Rb}$ ratios (Fig. 4d, e) and, to some extent, with the D50 values (Fig. 4f). Six main episodes of high terrigenous inputs (lowest $\mathrm{Ca} / \mathrm{Ti}$ ) are clearly expressed in the $\mathrm{XRF}$ data at $\sim 3500 \pm 170, \sim 2840 \pm 172, \sim 2200 \pm 145$, $\sim 1500 \pm 124, \sim 1010 \pm 75$ and $\sim 720 \pm 72$ a cal BP (Fig. 4 , Table 3). Considering the age uncertainty, only some of those events may coincide with CRs (CR6, CR5, CR4; Fig. 4). The peaks in the clay content correspond to low $\mathrm{Ca} / \mathrm{Ti}$ ra- 


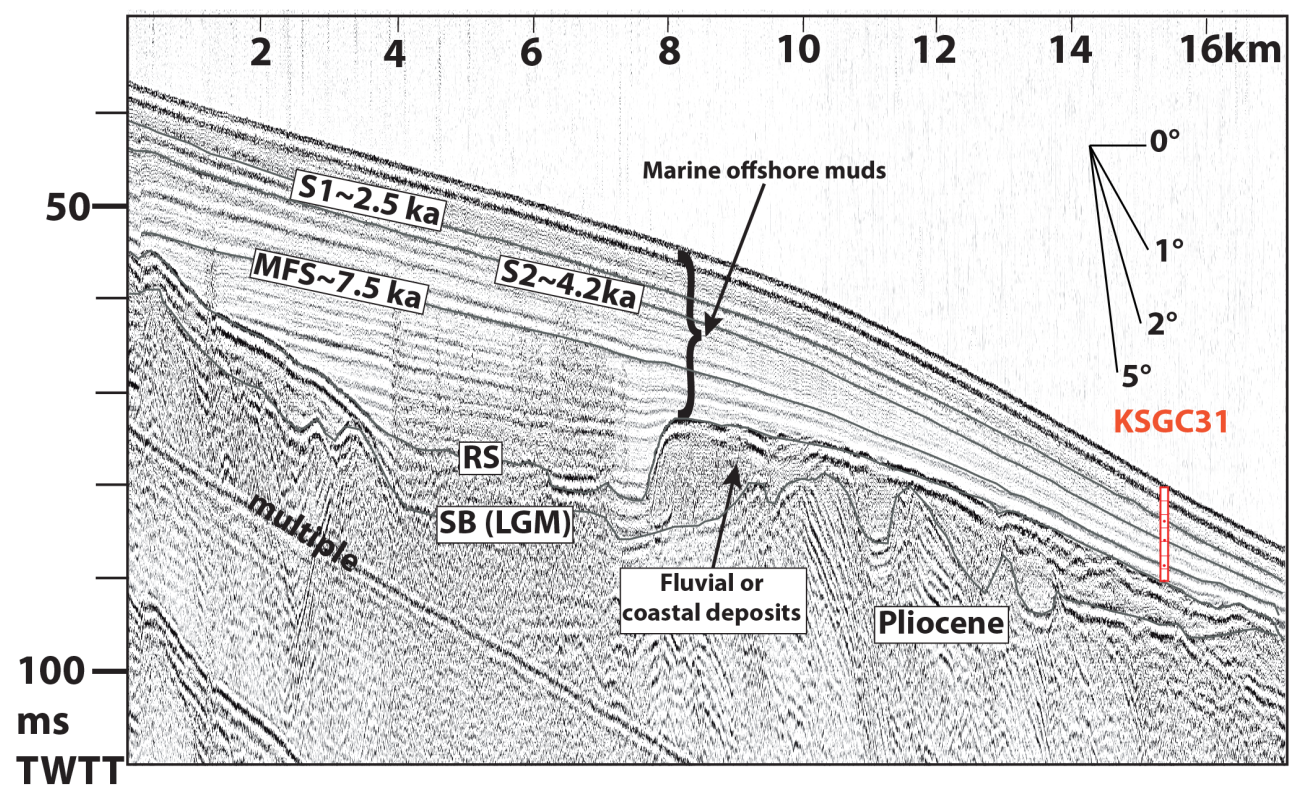

Figure 2. Seismic profile across the Rhône mud belt at the position of core KSGC31 (position in Fig. 1). SB: sequence boundary surface formed by continental erosion during the Last Glacial Maximum (LGM). RS: ravinement surface formed by wave erosion during sea-level rise. It corresponds to the coarse interval at the base of the core. MFS: maximum flooding surface. It corresponds to the phase of transition between coastal retrogradation and coastal progradation. It is dated here to ca. $7.5 \mathrm{ka}$ cal BP (i.e. the period of global sea-level stabilization). $\mathrm{S} 1$ and S2 are seismic surfaces used as time lines on the basis of the age model in Fig. 3 (respectively $4.2 \pm 0.5$ and $2.5 \pm 0.5 \mathrm{kacal} \mathrm{BP}$ ). Horizontal bars every meter along the core. Vertical scale in milliseconds two-way travel time (ms TWTT).

Table 2. ${ }^{14} \mathrm{C}$ dates obtained from core KSGC31.

\begin{tabular}{|c|c|c|c|c|c|c|}
\hline Depth $(\mathrm{cm})$ & Material & Laboratory & $\begin{array}{l}\text { Radiocarbon age } \\
\pm 1 \sigma \text { error }(\mathrm{yr} \mathrm{BP})\end{array}$ & $\begin{array}{r}\text { Calibrated age } \\
\text { (cal BP) }\end{array}$ & $\begin{array}{l} \pm 1 \sigma \\
\text { error }\end{array}$ & $\begin{array}{l}\text { Sedimentation rate } \\
(\mathrm{SR})\left(\mathrm{mm} \mathrm{yr}^{-1}\right)\end{array}$ \\
\hline 5.5 & Bittium sp. & Beta Analytics & $420 \pm 30$ & $24^{\mathrm{a}}$ & 60 & - \\
\hline 11.5 & Tellina sp. & Beta Analytics & $430 \pm 30$ & $34^{\mathrm{a}}$ & 60 & - \\
\hline 18.5 & Pecten sp. & Beta Analytics & $720 \pm 40$ & $350^{\mathrm{b}}$ & 78 & - \\
\hline 25.5 & Venus sp. & LMC14 & $640 \pm 30$ & 234 & 99 & 1.34 \\
\hline 41 & Pecten sp. & LMC14 & $700 \pm 30$ & 339 & 79 & 1.48 \\
\hline 52 & Indet. bivalve & LMC14 & $960 \pm 30$ & 551 & 59 & 0.52 \\
\hline 71 & Arca tetragona & LMC14 & $1340 \pm 30$ & 851 & 80 & 0.63 \\
\hline 110.5 & Venus sp. & LMC14 & $1465 \pm 30$ & 992 & 85 & 2.80 \\
\hline 186.5 & Nucula sp. & LMC14 & $2235 \pm 40$ & 1805 & 99 & 0.93 \\
\hline 251 & Juvenile bivalve shells (ind.) & LMC14 & $2940 \pm 30$ & 2674 & 100 & 0.74 \\
\hline 330.5 & Venus casina & LMC14 & $3870 \pm 30$ & 3796 & 106 & 0.71 \\
\hline 370.5 & Nuculana sp. & LMC14 & $4170 \pm 30$ & 4223 & 113 & 0.94 \\
\hline 390.5 & Turritella sp. & LMC14 & $4500 \pm 30$ & 4676 & 106 & 0.44 \\
\hline 460 & Venus sp. & LMC14 & $5530 \pm 45$ & 5873 & 106 & 0.58 \\
\hline 481 & Ostrea $\mathrm{sp}$ & LMC14 & $5955 \pm 35$ & 6348 & 78 & 0.44 \\
\hline 501.5 & Turritella sp. & LMC14 & $6380 \pm 50$ & 6826 & 107 & 0.43 \\
\hline 552 & Shells (mixed) & LMC14 & $7215 \pm 30$ & 7653 & 75 & 0.61 \\
\hline 583 & Turritella sp. & LMC14 & $7860 \pm 60$ & 8288 & 92 & 0.49 \\
\hline 652 & Turritella sp. & LMC14 & $8310 \pm 35$ & 8843 & 121 & 1.24 \\
\hline 700.5 & Turritella sp. & LMC14 & $9215 \pm 30$ & 10006 & 123 & 0.42 \\
\hline 701 & Turritella sp. & LMC14 & $9190 \pm 50$ & 9968 & 145 & - \\
\hline
\end{tabular}

${ }^{a}$ Post-bomb radiocarbon ages, obtained using OxCal 4.2 (Ramsey and Lee, 2013), not used for the interpolation. ${ }^{b}$ Reversal date, not used for the interpolation. 


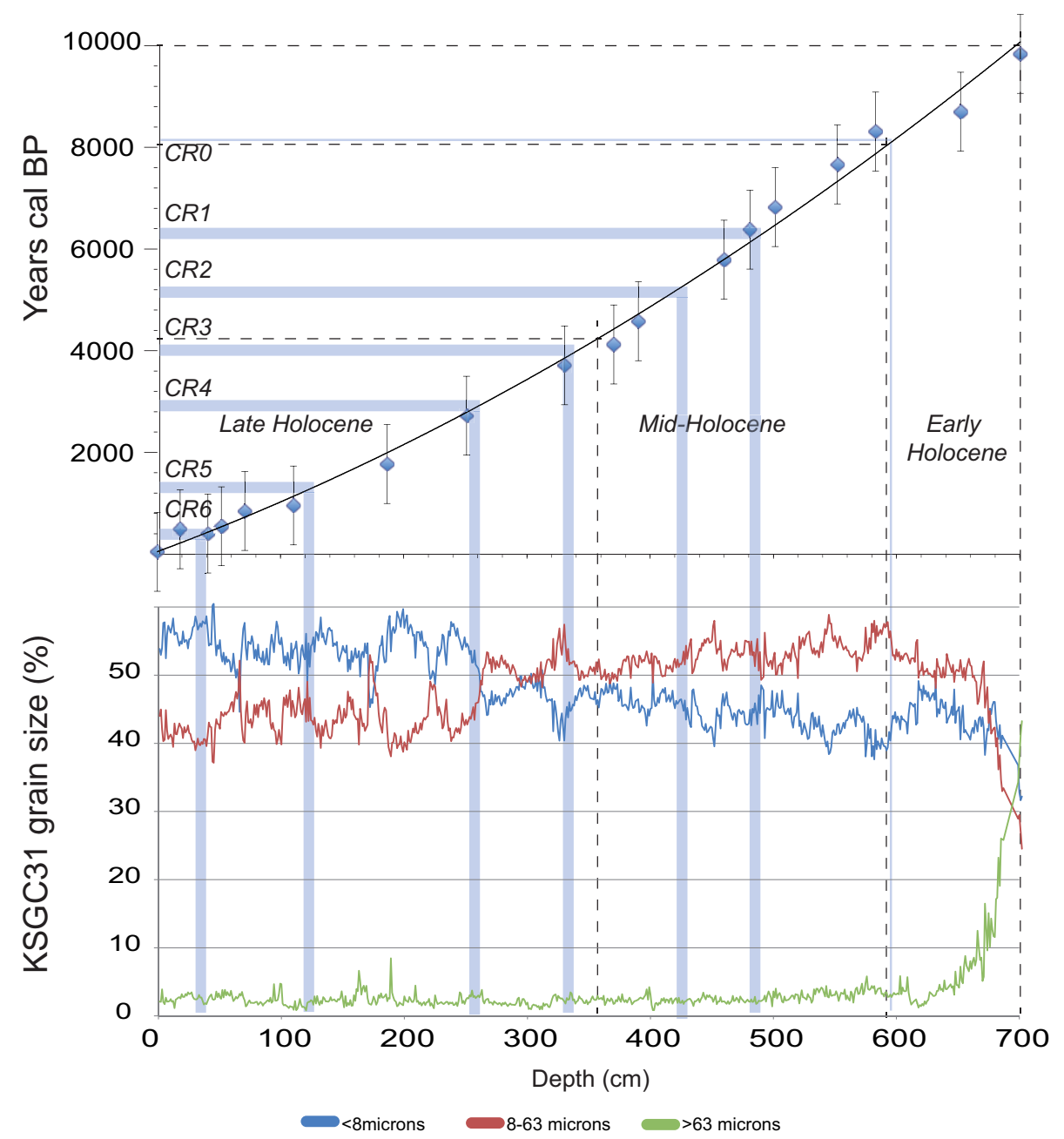

Figure 3. Correlation age-depth in core KSGC31. The Holocene time is divided into early, middle and late Holocene according to Walker et al. (2012). General core lithology is shown through the distribution of three grain size classes: $<8,8-63$ and $>63 \mu \mathrm{m}$.

tios of variable amplitude. The clay content of the 2840 and 2200 a cal BP events is among the highest ( $35 \%$; Fig. 5e). From 4200 a cal BP to the present, the $C: \mathrm{N}_{\mathrm{a}}$ values decrease gradually. Between $\sim 4200$ and $\sim 3200$ a cal BP, some values exceed 13. Thereafter, the $C: \mathrm{N}_{\mathrm{a}}$ values range between 9 and 10 (Fig. 4a). The late Holocene is also characterized by decreasing carbonate content with a drastic drop around 2000 a cal BP (Fig. 4b). The SR is also higher than during the mid-Holocene lying between 0.5 and $1 \mathrm{~mm} \mathrm{yr}^{-1}$.

\section{Interpretation and discussion}

Numerous forcing factors (sea level, ice cap extent, forest cover, volcanic activity, etc.) may account for the climate variability in the Holocene. Statistical analysis of proxy time series in both the Northern and the Southern Hemisphere (Wanner et al., 2011) have demonstrated that multidecadal to multicentury CRs interrupted periods of relatively stable climate conditions. They are demonstrated to exist at least in the North Atlantic (Bond, 1997) and the surrounding land areas. However, there is a general agreement about the different local expressions and timing offset of these rapid climate changes according to geographical position or geomorphological setting. In a way, these events cannot be considered truly global, but they nonetheless represent significant milestones in the Holocene climate history. In this paper, we use the correlation with CRs known from the literature (Table 3) in order to highlight possible differences in features and chronology of rapid events between the Atlantic and the western Mediterranean during the early, middle and late Holocene.

\subsection{Early Holocene (11.7-8.2 ka cal BP)}

The lower $20 \mathrm{~cm}$ of the core are made up of heterolithic coarse-grained sediments of continental origin mixed with abundant shell debris. This interval corresponds to the ravinement surface (RS) seen on seismic profiles (Fig. 2); 
(a)

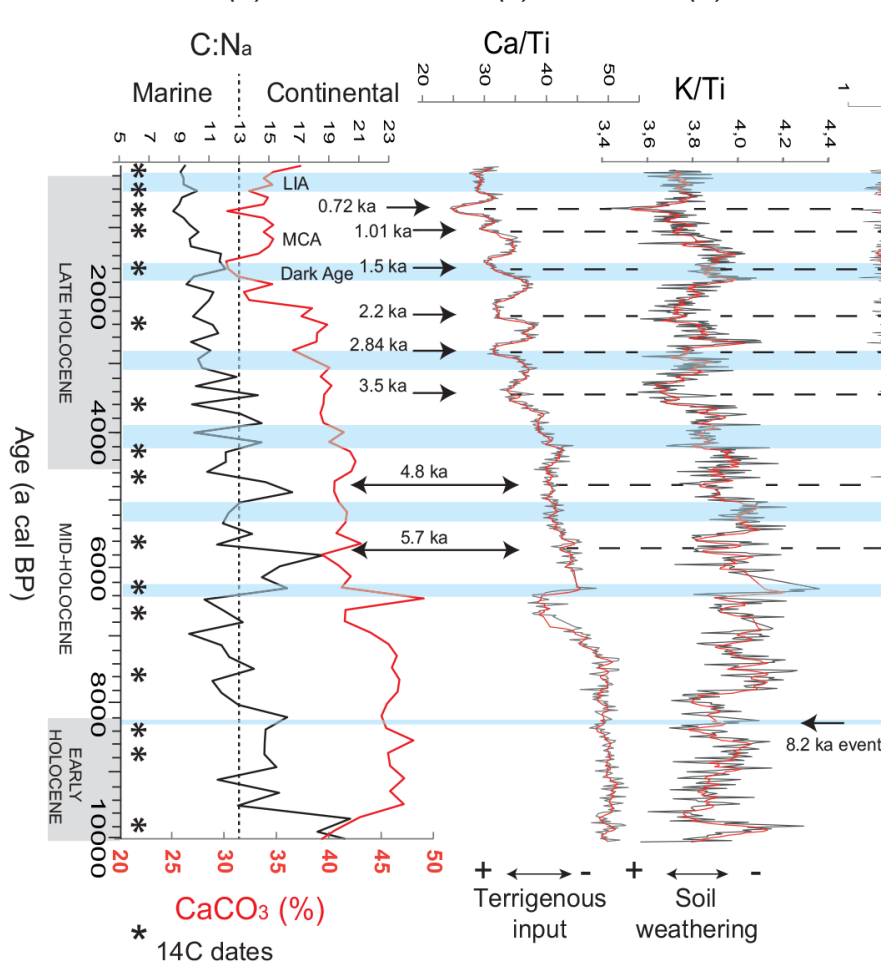

(e)

$\mathrm{Zr} / \mathrm{Rb}$ (f) (h)

(b)

Figure 4. KSGC31 geochemical and sedimentological proxies. (a) $\mathrm{C}: \mathrm{N}_{\mathrm{a}}$ atomic ratio is used as qualitative descriptor of organic matter nature. Values of $\mathrm{C}: \mathrm{N}_{\mathrm{a}}$ ratio $>13$ indicate significant amount of terrestrial organic matter, according to Goñi et al. (2003). (b) $\mathrm{CaCO}_{3}$ content (\%) calculated from $\mathrm{TC}-\mathrm{OC}$ using the molecular mass ratio $\left(\mathrm{CaCO}_{3}: \mathrm{C}=100: 12\right)$. (c) $\mathrm{Ca} / \mathrm{Ti}$ ratio is used for estimating the degree of detritism, since Ti is commonly found in terrigenous sediments. (d) $\mathrm{K} / \mathrm{Ti}$ ratio can be related to illite content, formed by weathering of $\mathrm{K}$-feldspars. Illite may be depleted in $\mathrm{K}$ upon pedogenetic processes; the $\mathrm{K} / \mathrm{Ti}$ ratio can be considered an indirect proxy for the intensity of chemical weathering (Arnaud et al., 2012). (e) $\mathrm{Zr} / \mathrm{Rb}$ is known to reflect changes in grain size; $\mathrm{Zr}$ is commonly associated with the relatively coarse-grained fraction of fine-grained sediments, whereas $\mathrm{Rb}$ is associated with the fine-grained fraction. (f) D50 represents the maximum diameter of $50 \%$ of the sediment grain size. These plots are correlated to the reconstruction of North Atlantic Oscillation (NAO) (g) from a lake in Greenland (Olsen et al., 2012) and reconstructed SST $\left(\mathbf{C}^{\circ}\right)$ from alkenones (h) in the same core (Jalali et al., 2016). Blue bands correspond to CR0-6 chronology; dotted black lines highlight the main wet events that may be observed in sediment records in the late Holocene (Table 3).

it was formed by transgressive erosion when the relative sea level was $-30 / 40 \mathrm{~m}$ lower than today. It is unconformably overlaid by fine-grained sediments that represent the initiation of the mud belt around $9000 \mathrm{a}$ cal BP. The $\sim 9-8.2 \mathrm{ka}$ interval is marked by highest SR values and high terrestrial supply, as also indicated by the high $\mathrm{C}: \mathrm{N}_{\mathrm{a}}$ ratio (>13) (Fig. 4a) (Buscail and Germain, 1997; Buscail et al., 1990; Gordon and Goñi, 2003; Kim et al., 2006). The $\mathrm{C}: \mathrm{N}_{\mathrm{a}}$ ratios $\sim 20$, indicative of even larger enrichment in organic material originating from soils or plant debris in the coarse deposit at the very bottom of the core $(700 \mathrm{~cm})($ Hedges and Oades, 1997; Meyers and Ishiwatari, 1993), are of note. A layer of high Turritella abundances is identified in the fine-grained sediments just above the sandy interval $(680-640 \mathrm{~cm}$, i.e. 8500-8000 a cal BP) (Fig. 3). Then Turritella shells disappear gradually towards the top of the core, suggesting an upward deepening environment. The high Turritella level could indicate a change in Northern Hemisphere climate and can be hypothetically related to the "Turritella Layer" described by Naughton et al. (2007) on the NW Atlantic shelf, therefore suggesting a regional change between 8700 and 8400 a cal BP, possibly in relation to the southward migration of the boreal biogeographical zone. The maximum flooding surface (MFS) is dated around $7500 \mathrm{acal} \mathrm{BP}$ (Fig. 2). This age may vary at different locations because it depends upon the ratio between sediment delivery and accommodation space, but it matches well the age of delta initiations observed worldwide by Stanley and Warne (1994).

The increase in K/ Ti between 9000 and 7000 acal BP may reflect the gradual decrease in the contribution of weathered material from the river catchment areas, which can thus be interpreted as a signal of weaker pedogenetic processes 


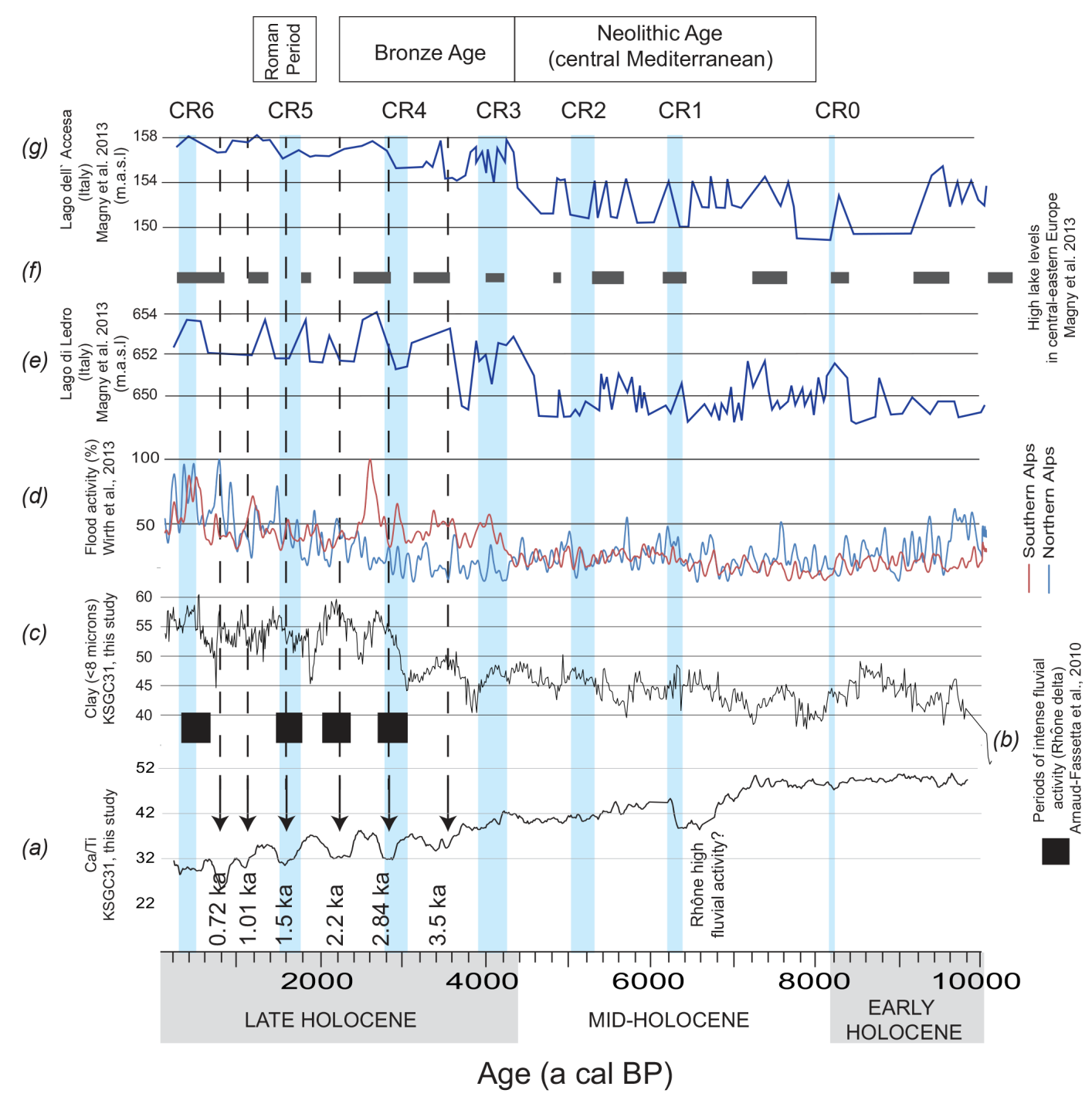

Figure 5. Ca / Ti ratio (a) and percentage of fine-grained $(<8 \mu \mathrm{m})$ sediment (c) compared to (b) periods of intense fluvial activity based on hydromorphological and paleohydrological changes in the Rhône Delta (Arnaud-Fassetta et al., 2010). (d) Holocene flood frequency (\%) in southern and northern Alps estimated on the basis on lake flood records by Wirth et al. (2013). (e-g) Lake level fluctuations in central and eastern Europe during the Holocene (Magny et al., 2013). Blue bands correspond to CR0-6 chronology; dotted black lines highlight the main wet events that may be observed in sediment records in the late Holocene (Table 3).

Table 3. Time uncertainty $(1 \sigma)$ of "wet" events identified by the $\mathrm{Ca} / \mathrm{Ti}$ and $\mathrm{K} / \mathrm{Ti}$ ratios (Fig. 4).

\begin{tabular}{lrrrrr}
\hline $\begin{array}{l}\text { Dates } \\
\text { in the text }\end{array}$ & $\begin{array}{r}\text { Start } \\
\text { (a cal BP) }\end{array}$ & $\begin{array}{r}\text { Maximum } \\
\text { (a cal BP) }\end{array}$ & $\begin{array}{r} \pm 1 \sigma \\
\text { uncertainty }\end{array}$ & $\begin{array}{r}\text { End } \\
\text { (a cal BP) }\end{array}$ & Proxy \\
\hline $0.72 \mathrm{ka}$ & 645 & 720 & 72 & 800 & $\mathrm{Ca} / \mathrm{Ti}$ \\
$1.01 \mathrm{ka}$ & 1000 & 1015 & 75 & 1070 & $\mathrm{Ca} / \mathrm{Ti}$ \\
$1.5 \mathrm{ka}$ & 1400 & 1500 & 124 & 1640 & $\mathrm{Ca} / \mathrm{Ti}$ \\
$2.2 \mathrm{ka}$ & 2080 & 2200 & 145 & 2300 & $\mathrm{Ca} / \mathrm{Ti}$ \\
$2.84 \mathrm{ka}$ & 2700 & 2840 & 172 & 2900 & $\mathrm{Ca} / \mathrm{Ti}$ \\
$3.5 \mathrm{ka}$ & 3350 & 3500 & 170 & 3615 & $\mathrm{Ca} / \mathrm{Ti}$ \\
$4.8 \mathrm{ka}$ & 4670 & 4800 & 150 & 4960 & $\mathrm{~K} / \mathrm{Ti}$ \\
$5.7 \mathrm{ka}$ & 5530 & 5700 & 162 & 5770 & $\mathrm{~K} / \mathrm{Ti}$ \\
\hline
\end{tabular}

and lower soil erosion due to a dry climate in the European Alps (Fig. 4d) (Arnaud et al., 2012).

The period between $\sim 12000$ and 7000 a cal BP is marked by a continuous retreat of Arctic continental ice sheets until the complete disappearance of the Fennoscandian and Laurentide ice cap (Tornqvist and Hijma, 2012; Ullman et al., 2015). Ice sheet melting is seen in the general sealevel rise and also manifested by short-lived water releases into the ocean, occasionally perturbing the North Atlantic Ocean circulation and climate over Europe (for example the 8200 cal BP event, here CR0). It is worth noting that around CR0, the $\mathrm{K} / \mathrm{Ti}$ ratio shows a peak within an interval of low values between approximately 7900 and 8300 a cal BP. This 
peak would identify an increase in continental supply and low chemical weathering corresponding to cold (weak soil formation) and wet (high physical erosion) conditions over midlatitude Europe in response to the 8200 a cal BP cooling (Arnaud et al., 2012; Magny et al., 2003). This phenomenon is also attested to by higher lake levels in western Europe (Fig. 5d, f) concurrent with CR0 (Magny et al., 2013). Note that no clear temperature drop in the alkenone-derived sea surface temperature (SST) generated in the core has been detected (Jalali et al., 2016).

\subsection{Mid-Holocene (8.2-4.2 ka cal BP)}

Values of $C: N_{a}$ ratios are mainly $>13$ (Fig. 4a) between 6.3 and $4.4 \mathrm{kacal} \mathrm{BP}$, while $\mathrm{Ca} / \mathrm{Ti}$ shows a slight progressive decrease that can be interpreted as an increase in terrestrial inputs during the mid-Holocene, despite the increasing distance of the KSGC31 site from river outlets due to sea-level rise and the progressive shift of the Rhône Delta to the east (Fanget et al., 2014).

The mid-Holocene is described as a period of relatively mild and high atmospheric moisture balance (Cheddadi et al., 1998) that favored the maximum expansion of the mesophytic forest leading to maximum land cover over Europe. Nonetheless, two main short-lived climate anomalies are reported at $6600-5700$ acalBP (CR1, Tables 1 and 3) and 5300-5000 a cal BP (CR2, Tables 1 and 3) over the North Atlantic (Wanner et al., 2011) and in Europe (Magny and Haas, 2004; Robert et al., 2011), at the time of global cooling. $\mathrm{CR} 1$ is associated with a drying climate in eastern Europe and Asia and has been related to the weakening of the Asian monsoon and the decrease in summer insolation (Gasse et al., 1991), while CR2 coincides with weaker solar activity as indicated by maximum atmospheric ${ }^{14} \mathrm{C}$ around 5600 5200 a cal BP (Stuiver et al., 2006), lower tree lines (Magny and Haas, 2004) and colder sea surface temperatures (Jalali et al., 2016).

According to our data, during CR1 and CR2, chemical weathering was weak as suggested by high $\mathrm{K} / \mathrm{Ti}$ values (Fig. 4d) and mean SR was generally low $\left(<1 \mathrm{~mm} \mathrm{yr}^{-1}\right.$ on average; Table 2), but there was no significant change in terrigenous inputs ( $\mathrm{Ca} / \mathrm{Ti}$ ratio; Fig. $4 \mathrm{c})$. The $\mathrm{C}: \mathrm{N}_{\mathrm{a}}$ ratios indicate better preservation of nitrogen organic compounds preferentially adsorbed in the clay fraction (Fig. 4a). The reduction in the vegetation cover in the river catchment, combined with lower $\left(1-1.5^{\circ} \mathrm{C}\right)$ temperatures in the European Alps (Haas et al., 1998), may explain the low chemical degradation state of the illite minerals. A drop in sea surface temperature is also recorded by alkenones in the core, as illustrated in Jalali et al. (2016), confirming the impact of the cold relapses in the Mediterranean area in the mid-Holocene (Fig. 4h).

\subsection{Late Holocene (4.2-0 ka cal BP)}

Multidecadal to century-scale wet episodes are evidenced from $\sim 4200$ a cal BP, which marks the mid-late Holocene transition (Fig. 3). In the KSGC31 core, wetter intervals are expressed by highly fluctuating $\mathrm{Ca} / \mathrm{Ti}, \mathrm{Zr} / \mathrm{Rb}$ and $\mathrm{K} / \mathrm{Ti}$ ratios, $C: N_{a}$, and grain size values (Fig. 4 and Table 3 ). From the present to $3.5 \mathrm{kacal} \mathrm{BP}$, the $\mathrm{C}: \mathrm{N}_{\mathrm{a}}$ ratio shows an increase from 9 to 11 (Fig. 4), testifying to active diagenetic processes due to preferential degradation of nitrogen relative to carbon during burial. Some values $>13$ are still observed between 4200 and 3500 a cal BP, indicating enhanced terrestrial inputs. Episodes of enhanced terrigenous inputs (during floods, for instance) are detected by low $\mathrm{Ca} / \mathrm{Ti}$ ratios that also coincide with low $\mathrm{Zr} / \mathrm{Rb}$ and low D50 values, indicating general, smaller-size terrigenous grains as also suggested by high clay content (Fig. 5c). Indeed, after the stabilization of the sea level, only the finest sediment fraction (clay) transported by the river plume reaches the mud belt at the core site.

An exception to this pattern is observed for the LIA, when quite high $\mathrm{Ca} / \mathrm{Ti}$ would suggest relatively dry conditions (Fig. 4c, f). The qualitative observation under the binocular microscope of the coarse $(>63 \mu \mathrm{m})$ fraction reveals the presence (only in this specific interval) of abundant bryozoans and Elphidium crispum (coastal benthic foraminifer) tests together with rare grains of quartz. The biogenic debris can explain the high $\mathrm{Ca}$ content and presence of quartz grains, the peak of $\mathrm{Zr} / \mathrm{Rb}$ (Fig. 4e). The accumulation of this material is maybe due to the concomitant occurrence of river floods (Fig. 5d) and storms, which may have remobilized coarse material from a coastal setting (Bourrin et al., 2015).

Thus, intensified hydrological activity associated with high terrestrial inputs would have prevailed during the late Holocene, as also suggested by higher SR (Table 2). The enhanced terrestrial inputs are inferred from XRF ratios and discussed in this work, but the biomarker data in Jalali et al. (2016) also highlighted enhanced flood activity during the late Holocene. The TERR-alkane (alkenones and highmolecular-weight odd-carbon numbered $n$-alkanes) concentrations are among the highest of the entire Holocene record, with maxima recorded during Common Era (last 2000 years).

A similar signature of continental runoff in marine sediments (low $\mathrm{Ca} / \mathrm{Ti}$ ratio) during the past $\sim 6500$ years has been reported in the central Mediterranean and related to climatically driven wet periods (Goudeau et al., 2014). In the KSGC31, these events ( $\sim 2840 \mathrm{a}, \sim 1500$ and $\sim 720$ a cal BP; Fig. 4) barely coincide with the cold events in the North Atlantic but are concomitant with periods of increasing flood frequency in the northern Alps as reconstructed by Wirth et al. (2013) (Fig. 5d) and punctuated by overall warm (and dry) periods such as the MCA at $\sim 3.500$, $\sim 2.200, \sim 1.000$ and $\sim 0.72$ a cal BP (Fig. 4). This pattern suggests different causes for enhanced precipitation in the late Holocene. 
A possible control of the North Atlantic Oscillation (NAO) on the amount of precipitation in the Mediterranean land areas may be put forward. The NAO exerts a strong influence on the precipitation pattern in Europe and the NW Mediterranean region. Today, precipitation in the western Mediterranean region and southern France is lower during positive NAO. Rainfall increases under negative NAO due to the southern shift of the Atlantic storm tracks leading to enhanced cyclogenesis in the Mediterranean Sea (Trigo et al., 2000). The position of the ITCZ is also important in the precipitation pattern of the Mediterranean region, and its southernmost position is the probable cause for extremely dry conditions between 2500 and 2000 a cal BP (Schimmelpfennig et al., 2012). The reconstructed NAO index (Olsen et al., 2012) indicates a predominance of positive states between 5000-4500 and 2000-550 a cal BP (Fig. 4g), in agreement with (a) an increased frequency of floods in the northern Alps (Fig. 5d; Wirth et al., 2013) and (b) higher lake levels at Accesa (central Italy), at Ledro (northern Italy) and in central-western Europe (Magny et al., 2013), all together suggesting more humid conditions in west-central Europe (Fig. 5d, f).

Late Holocene human settlements along the Rhône Valley and southern France may also have had an impact on the origin and amounts of eroded sediments in the river catchment areas. The chemical signature of KSGC 31 sediments shows that low $\mathrm{K} / \mathrm{Ti}$ ratios, reflecting soil weathering due to terrain degradation, are coeval with wet events (Fig. 4d). It could be interpreted as the result of widespread deforestation by agropastoral activities in this area since the end of the Neolithic. The most extensive erosion episodes in the Rhône Valley correspond to (1) the end of the Neolithic ( $4000 \mathrm{BC}$; $6000 \mathrm{a}$ cal BP) after the first phase of human expansion linked to the development of agriculture, 2) the end of the Bronze Age ( 2000 BC; 4000 a cal BP), and 3) the Roman period, when a rapid transformation of landscape is operated by deforestation and the replacement of forest by intensively cultivated agricultural land (van der Leeuw, 2005).

Disentangling human impact from climate control on environmental changes in the late Holocene is not an easy task and requires the study of other river catchment basins to confirm the regional character of these observations. However, assuming that climate variability is the major factor influencing soil pedogenesis, we can hypothesize that the elemental composition of marine sediments reflects continental erosion and transport because of a good correspondence with temperature variability in the Mediterranean Sea along the same core (Jalali et al., 2016) and because, on a regional scale, both marine and continental climate proxies indicate coeval signals (Arnaud et al., 2012; Goudeau et al., 2014) . Despite the fact that the characteristics in amplitude and duration of these climate intervals differ slightly geographically, there seems to be a general agreement on their origin and the role of solar forcing and large-scale atmospheric circulation. However, the amplification of soil degradation following waves of hu- man occupation should be further explored through the accurate correlation of archeological data and paleoenvironmental proxies in order to better evaluate the importance of land use for sedimentary signals.

\section{Conclusions}

This work represents the first attempt to detect and decipher the linkages between rapid climate changes and continental paleohydrology in the NW Mediterranean shallow marine setting during the Holocene.

Based on the combination of sedimentological and geochemical proxies we could demonstrate that between 11 and $4 \mathrm{ka} \mathrm{cal} \mathrm{BP}$, terrigenous input broadly increased. A Turritellarich interval is observed in the 8.5-8 ka cal BP interval, which could correspond to a change in Northern Hemisphere climate and can be correlated to the "Turritella Layer" described in the NW Atlantic shelf, possibly in relation to the southward migration of the boreal biogeographical zone.

From ca. 4000 a cal BP to present, the sediment flux proxies indicate enhanced variability in the amount of landderived material delivered to the Mediterranean by the Rhône River input. We suggest that this late Holocene variability is due to changes in large-scale atmospheric circulation and rainfall patterns in western Europe, including the increased variability of extension and retreat of Alpine glaciers. Anthropogenic impacts such as deforestation, resulting in higher sediment flux into the Gulf of Lions, are also likely and should be taken into account better in the future.

Acknowledgements. We thank MISTRALS/PALEOMEX for financial support and the crew operating the GMO2-Carnac (R/V Le Suroît) and GolHo (R/V Néréis) cruises. Nabil Sultan and the crew and science parties aboard R/V Suroit (IFREMER) retrieved core KSGC31 during the GMO2-Carnac cruise. The captain and crew of R/V Néréis (Observatoire Océanologique de Banyuls) as well as Olivier Raynal and Raphael Certain (CEFREM) are thanked for their assistance during the MADHO 1 cruise. ARTEMIS (Saclay, France) program is acknowledged for performing the ${ }^{14} \mathrm{C}$ measurements. Two anonymous reviewers are acknowledged for providing suggestions that allowed us to improve the quality of the manuscript. S. Luening is thanked for commenting on the manuscript during the open discussion.

Edited by: B. Martrat

Reviewed by: two anonymous referees

\section{References}

Aloisi, J. C., Auffret, G. A., Auffret, J. P., Barusseau, J. P., Hommeril, P., Larsonneur, C., and Monaco, A.: Essai de modelisation de la sedimentation actuelle sur les plateaux continentaux francais, B. Soc. Geol. Fr., 7, 183-195, 1977. 
Anchukaitis, K. and Tierney, J.: Identifying coherent spatiotemporal modes in time-uncertain proxy paleoclimate records, Clim. Dynam., 41, 1291-1306, 2013.

Arnaud-Fassetta, G.: Dynamiques fluviales holocènes dans le delta du Rhône, PhD, UFR des Sciences Géographiques, Université de Provence, Aix en Provence, 329 pp., 1998.

Arnaud-Fassetta, G.: The Upper Rhône Delta Sedimentary Record in the Arles-Piton Core: Analysis of Delta-Plain Subenvironments, Avulsion Frequency, Aggradation Rate and Origin of Sediment Yield, Geogr. Ann. A, 86, 367-383, 2004.

Arnaud-Fassetta, G., De Beaulieu, J.-L., Suc, J.-P., Provansal, M., Williamson, D., Leveau, P., Aloïsi, J.-C., Gadel, F., Giresse, P., Oberlin, C., and Duzer, D.: Evidence for an early land use in the Rhône delta (Mediterranean France) as recorded by late Holocene fluvial paleoenvironments (1640-100 BC), Geodin. Acta, 13, 377-389, 2000.

Arnaud-Fassetta, G., Carcaud, N., Castanet, C., and Salvador, P. G.: Fluviatile palaeoenvironments in archaeological context: Geographical position, methodological approach and global change - Hydrological risk issues, Quatern. Int., 216, 93-117, 2010.

Arnaud, F., Révillon, S., Debret, M., Revel, M., Chapron, E., Jacob, J., Giguet-Covex, C., Poulenard, J., and Magny, M.: Lake Bourget regional erosion patterns reconstruction reveals Holocene NW European Alps soil evolution and paleohydrology, Quaternary Sci. Rev., 51, 81-92, 2012.

Barber, D. C., Dyke, A., Hillaire-Marcel, C., Jennings, A. E., Andrews, J. T., Kerwin, M. W., Bilodeau, G., McNeely, R., Southon, J., Morehead, M. D., and Gagnon, J. M.: Forcing of the cold event of 8,200 years ago by catastrophic drainage of Laurentide lakes, Nature, 400, 344-348, 1999.

Bassetti, M. A., Jouet, G., Dufois, F., Berne, S., Rabineau, M., and Taviani, M.: Sand bodies at the shelf edge in the Gulf of Lions (Western Mediterranean): Deglacial history and modern processes, Mar. Geol., 234, 93-109, 2006.

Benito, G., Sopeña, A., Sánchez-Moya, Y., Machado, M. A. J., and Pérez-González, A.: Palaeoflood record of the Tagus River (Central Spain) during the Late Pleistocene and Holocene, Quaternary Sci. Rev., 22, 1737-1756, 2003.

Benito, G., Macklin, M. G., Zielhofer, C., Jones, A. F., and Machado, M. J.: Holocene flooding and climate change in the Mediterranean, CATENA, 130, 13-33, 2015.

Berné, S. and Gorini, C.: The Gulf of Lions: An overview of recent studies within the French "Margins" programme, Mar. Petrol. Geol., 22, 691-693, 2005.

Berné, S., Rabineau, M., Flores, J. A., and Sierro, F. J.: The impact of Quaternary Global Changes on Strata Formation. Exploration of the shelf edge in the Northwest Mediterranean Sea, Oceanography, 17, 92-103, 2004.

Berné, S., Jouet, G., Bassetti, M. A., Dennielou, B., and Taviani, M.: Late Glacial to Preboreal sea-level rise recorded by the Rhone deltaic system (NW Mediterranean), Mar. Geol., 245, 65-88, 2007.

Bond, G.: A pervasive millennial-scale cycle in North Atlantic Holocene and Glacial climates, Science, 278, 1257-1266, 1997.

Bonneau, L., Jorry, S. J., Toucanne, S., Jacinto, R. S., and Emmanuel, L.: Millennial-Scale Response of a Western Mediterranean River to Late Quaternary Climate Changes: A View from the Deep Sea, J. Geol., 122, 687-703, 2014.
Bourrin, F., Many, G. , Durrieu de Madron, X., Martin, P., Houper, L., Testor, P., Kunesch, S., Mahiouz, K., and Beguery, L.: Glider monitoring of shelf suspended particle dynamics and transport during storm and flooding conditions, Cont. Shelf Res., 109, 135-149, 2015.

Ramsey, C. B. and Lee, S.: Recent and Planned Developments of the Program OxCal, 55, 720-730, 2013.

Buscail, R. and Germain, C.: Present-day organic matter sedimentation on the NW Mediterranean margin: Importance of off-shelf export, Limnol. Oceanogr., 42, 217-229, 1997.

Buscail, R., Pocklinton, R., Daumas, R., and Guidi, L.: Fluxes and budget of organic matter in the benthic boundary layer over the northwestern Mediterranean margin, Cont. Shelf Res., 10, 1089$1122,1990$.

Calmet, D. and Fernandez, J.-M.: Caesium distribution in northwest Mediterranean seawater, suspended particles and sediment, Cont. Shelf Res., 10, 895-913, 1990.

Cattaneo, A., Correggiari, A., Langone, L., and Trincardi, F.: The late-Holocene Gargano subaqueous delta, Adriatic shelf: Sediment pathways and supply fluctuations, Mar. Geol., 193, 61-91, 2003.

Cauwet, G., Gadel, F., de Souza Sierra, M. M., Donard, O., and Ewald, M.: Contribution of the Rhone River to organic carbon inputs to the northwestern Mediterranean Sea, Cont. Shelf Res., 10, 1025-1037, 1990.

Chambers, F. M., Mauquoy, D., Brain, S. A., Blaauw, M., and Daniell, J. R. G.: Globally synchronous climate change 2800 years ago: Proxy data from peat in South America, Earth Planet. Sc. Lett., 253, 439-444, 2007.

Chamley, H.: Recherches sur la sédimentation argileuse en Méditerranée, PhD, Université Aix Marseille, Marseille, 209 pp., 1971.

Charmasson, S., Radakovitch, O., Arnaud, M., Bouisset, P., and Pruchon, A.-S.: Long-core profiles of ${ }^{137} \mathrm{Cs},{ }^{134} \mathrm{Cs},{ }^{60} \mathrm{Co}$ and ${ }^{210} \mathrm{~Pb}$ in sediment near the Rhône River (Northwestern Mediterranean Sea), Estuaries, 21, 367-378, 1998.

Cheddadi, R., Lamb, H. F., Guiot, J., and van der Kaars, S.: Holocene climatic change in Morocco: a quantitative reconstruction from pollen data, Clim. Dynam., 14, 883-890, 1998.

Do Carmo, D. A. and Sanguinetti, Y. T.: Taxonomy and palaeoceanographical significance of the genus Krithe (Ostracoda) in the Brazilian margin, J. Micropalaeontol., 18, 111-123, 1999.

Durrieu De Madron, X., Abassi, A., Heussner, S., Monaco, A., Aloisi, J. C., Radakovitch, O., Giresse, P., Buscail, R., and Kerherve, P.: Particulate matter and organic carbon budgets for the Gulf of Lions (NW Mediterranean), Oceanol. Acta, 23, 717-730, 2000.

Dypvik, H. and Harris, N. B.: Geochemical facies analysis of finegrained siliciclastics using $\mathrm{Th} / \mathrm{U}, \mathrm{Zr} / \mathrm{Rb}$ and $(\mathrm{Zr}+\mathrm{Rb}) / \mathrm{Sr}$ ratios, Chem. Geol., 181, 131-146, 2001.

Estournel, C., Durrieu de Madron, X., Marsaleix, P., Auclair, F., Julliand, C., and Vehil, R.: Observation and modeling of the winter coastal oceanic circulation in the Gulf of Lion under wind conditions influenced by the continental orography (FETCH experiment), J. Geophys. Res., 108, 8059, doi:10.1029/2001JC000825, 2003.

Evans, M. N., Tolwinski-Ward, S. E., Thompson, D. M., and Anchukaitis, K. J.: Applications of proxy system modeling in high resolution paleoclimatology, Quaternary Sci. Rev., 76, 16-28, 2013. 
Eyrolle, F., Radakovitch, O., Raimbault, P., Charmasson, S., Ferrand, E., Antonelli, C., Jacquet, S., Aubert, D., Raccasi, G., and Gurriaran, R.: Hydrological events on suspended sediment and associated radionuclide deliveries from the Rhône River towards the Mediterranean Sea, J. Soils Sediment., 2, 1479-1495, 2012.

Fanget, A. S., Bassetti, M. A., Arnaud, M., Chiffoleau, J. F., Cossa, D., Goineau, A., Fontanier, C., Buscail, R., Jouet, G., Maillet, G. M., Negri, A., Dennielou, B., and Berné, S.: Historical evolution and extreme climate events during the last 400 years on the Rhone prodelta (NW Mediterranean), Mar. Geol., 346, 375-391, 2013.

Fanget, A.-S., Berné, S., Jouet, G., Bassetti, M.-A., Dennielou, B., Maillet, G. M., and Tondut, M.: Impact of relative sea level and rapid climate changes on the architecture and lithofacies of the Holocene Rhone subaqueous delta (Western Mediterranean Sea), Sediment. Geol., 305, 35-53, 2014.

Faust, D., Zielhofer, C., Baena Escudero, R., and Diaz del Olmo, F.: High-resolution fluvial record of late Holocene geomorphic change in northern Tunisia: climatic or human impact?, Quaternary Sci. Rev., 23, 1757-1775, 2004.

Fletcher, W. J. and Sánchez Goñi, M. F.: Orbital- and sub-orbitalscale climate impacts on vegetation of the western Mediterranean basin over the last 48,000 yr, Quaternary Res., 70, 451-464, 2008.

Gasse, F., Arnold, M., Fontes, J. C., Fort, M., Gibert, E., Huc, A., Bingyan, L., Yuanfang, L., Qing, L., Melieres, F., Campo, E. V., Fubao, W., and Qingsong, Z.: A 13,000-year climate record from western Tibet, Nature, 353, 742-745, 1991.

Gensous, B. and Tesson, M.: L'analyse des dépôts postglaciaires et son application à l'étud des séquences de dépôt du Quaternaire terminal sur la plate-forme au large du Rhône (golfe du Lion), B. Soc. Geol. Fr., 174, 401-419, 2003.

Goñi, M. A., Teixeira, M. J., and Perkey, D. W.: Sources and distribution of organic matter in a river-dominated estuary (Winyah Bay, SC, USA), Estuar. Coast. Shelf S., 57, 1023-1048, 2003.

Gordon, E. S. and Goñi, M. A.: Sources and distribution of terrigenous organic matter delivered by the Atchafalaya River to sediments in the northern Gulf of Mexico, Geochim. Cosmochim. Ac., 67, 2359-2375, 2003.

Goudeau, M.-L. S., Grauel, A.-L., Tessarolo, C., Leider, A., Chen, L., Bernasconi, S. M., Versteegh, G. J. M., Zonneveld, K. A. F., Boer, W., Alonso-Hernandez, C. M., and De Lange, G. J.: The Glacial-Interglacial transition and Holocene environmental changes in sediments from the Gulf of Taranto, central Mediterranean, Mar. Geol., 348, 88-102, 2014.

Haas, J. N., Richoz, I., Tinner, W., and Wick, L.: Synchronous Holocene climatic oscillations recorded on the Swiss Plateau and at timberline in the Alps, Holocene, 8, 301-309, 1998.

Hedges, J. I. and Oades, J. M.: Comparative organic geochemistries of soils and marine sediments, Org. Geochem., 27, 319-361, 1997.

Hill, P. S., Fox, J. S., Crockett, J. S., Kurran, K. J., Friedrichs, C. T., Geyer, W. R., Milligan, T. G., Ogston, A. P., Puig, P., Scully, M. E., Traykovski, P. A., and Wheatcroft, R. A.: Sediment delivery to the seabed on continental margins, IAS Special Publication 37, 49-99, 2007.

Jalali, B., Sicre, M.-A., Bassetti, M.-A., and Kallel, N.: Holocene climate variability in the North-Western Mediterranean Sea (Gulf of Lions), Clim. Past, 12, 91-101, doi:10.5194/cp-12-91-2016, 2016.

Josey, S. A., Somot, S., and Tsimplis, M.: Impacts of atmospheric modes of variability on Mediterranean Sea surface heat exchange, J. Geophys. Res.-Oceans, 116, doi:10.1029/2010JC006685, 2011.

Jouet, G.: Enregistremetns stratigraphiques des cycles climatiques et glacio-eustatiques du Quaternaire terminal, Modélisation de la marge continentale du Golfe du Lion, Université de Bretagne Occidentale, Brest, 443 pp., 2007.

Kim, J.-H., Schouten, S., Buscail, R., Ludwig, W., Bonnin, J., Sinninghe Damsté, J. S., and Bourrin, F.: Origin and distribution of terrestrial organic matter in the NW Mediterranean (Gulf of Lions): Exploring the newly developed BIT index, Geochem. Geophy. Geosy., 7, doi:10.1029/2006GC001306, 2006.

Konert, M. and Vandenberghe, J. E. F.: Comparison of laser grain size analysis with pipette and sieve analysis: a solution for the underestimation of the clay fraction, Sedimentology, 44, 523535, 1997.

L'Homer, A., Bazile, F., Thommeret, J., and Thommeret, Y.: Principales étapes de l'édification du delta du Rhône de 7000 B.P. à nos jours; variations du niveau marin, Oceanis, 7, 389-408, 1981.

Lombo Tombo, S., Dennielou, B., Berné, S., Bassetti, M. A., Toucanne, S., Jorry, S. J., Jouet, G., and Fontanier, C.: Sea-level control on turbidite activity in the Rhone canyon and the upper fan during the Last Glacial Maximum and Early deglacial, Sediment. Geol., 323, 148-166, 2015.

Magny, M. and Haas, J. N.: A major widespread climatic change around 5300 cal. yr BP at the time of the Alpine Iceman, J. Quaternary Sci., 19, 423-430, 2004.

Magny, M., Bégeot, C., Guiot, J., and Peyron, O.: Contrasting patterns of hydrological changes in Europe in response to Holocene climate cooling phases, Quaternary Sci. Rev., 22, 1589-1596, 2003.

Magny, M., Combourieu-Nebout, N., de Beaulieu, J. L., BoutRoumazeilles, V., Colombaroli, D., Desprat, S., Francke, A., Joannin, S., Ortu, E., Peyron, O., Revel, M., Sadori, L., Siani, G., Sicre, M. A., Samartin, S., Simonneau, A., Tinner, W., Vannière, B., Wagner, B., Zanchetta, G., Anselmetti, F., Brugiapaglia, E., Chapron, E., Debret, M., Desmet, M., Didier, J., Essallami, L., Galop, D., Gilli, A., Haas, J. N., Kallel, N., Millet, L., Stock, A., Turon, J. L., and Wirth, S.: North-south palaeohydrological contrasts in the central Mediterranean during the Holocene: tentative synthesis and working hypotheses, Clim. Past, 9, 20432071, doi:10.5194/cp-9-2043-2013, 2013.

Meyers, P. A. and Ishiwatari, R.: Lacustrine organic geochemistry - an overview of indicators of organic matter sources and diagenesis in lake sediments, Org. Geochem., 20, 867-900, 1993.

Millot, C.: The Gulf of Lions' hydrodynamics, Cont. Shelf Res., 10, 885-894, 1990.

Moloney, C. and Field, J.: Modelling Carbon and Nitrogen Flows in a Microbial Plankton Community, in: Protozoa and Their Role in Marine Processes, edited by: Reid, P. C., Turley, C. M., and Burkill, P. H., NATO ASI Series, Springer, Berlin, Heidelberg, 1991.

Monaco, A., Courp, T., Heussner, S., Carbonne, J., Fowler, S. W., and Deniaux, B.: Seasonality and composition of particulate fluxes during ECOMARGE-I, western Gulf of Lions, Cont. Shelf Res., 10, 959-987, 1990. 
Naudin, J. J., Cauwet, G., Chrétiennot-Dinet, M. J., Deniaux, B., Devenon, J. L., and Pauc, H.: River Discharge and Wind Influence Upon Particulate Transfer at the Land-Ocean Interaction: Case Study of the Rhone River Plume, Estuarine, Coast. Shelf Sci., 45, 303-316, 1997.

Naughton, F., Bourillet, J.-F., Sánchez Goñi, M. F., Turon, J.-L., and Jouanneau, J.-M.: Long-term and millennial-scale climate variability in northwestern France during the last 8850 years, Holocene, 17, 939-953, 2007.

Olsen, J., Anderson, N. J., and Knudsen, M. F.: Variability of the North Atlantic Oscillation over the past 5,200 years, Nat. Geosci., 5, 808-812, 2012.

PAGES-2k-Consortium: Continental-scale temperature variability during the past two millennia, Nat. Geosci., 6, 339-346, 2013.

Petrenko, A. A.: Variability of circulation features in the Gulf of Lion NW Mediterranean Sea. Importance of inertial currents, Oceanol. Acta, 26, 323-338, 2003.

Pont, D., Simonnet, J. P., and Walter, A. V.: Medium-term Changes in Suspended Sediment Delivery to the Ocean: Consequences of Catchment Heterogeneity and River Management (Rhône River, France), Estuar. Coast. Shelf S., 54, 1-18, 2002.

Posamantier, H. W. and Allen, G. P.: Siliciclastic sequence stratigraphy: concepts and applications, Society for Sedimentary Geology, Tulsa, 1999.

Renssen, H., Seppa, H., Heiri, O., Roche, D. M., Goosse, H., and Fichefet, T.: The spatial and temporal complexity of the Holocene thermal maximum, Nat. Geosci., 2, 411-414, 2009.

Richter, T. O., van der Gaast, S., Koster, B., Vaars, A., Gieles, R., de Stigter, H. C., De Haas, H., and van Weering, T. C. E.: The Avaatech XRF Core Scanner: technical description and applications to NE Atlantic sediments, Geological Society, London, Special Publications, 267, 39-50, 2006.

Roberts, N., Brayshaw, D., Kuzucuoğlu, C., Perez, R., and Sadori, L.: The mid-Holocene climatic transition in the Mediterranean: Causes and consequences, Holocene, 21, 3-13, 2011.

Rogerson, M., Schönfeld, J., and Leng, M. J.: Qualitative and quantitative approaches in palaeohydrography: A case study from core-top parameters in the Gulf of Cadiz, Mar. Geol., 280, 150167,2011

Schimmelpfennig, I., Schaefer, J. M., Akçar, N., Ivy-Ochs, S., Finkel, R. C., and Schlüchter, C.: Holocene glacier culminations in the Western Alps and their hemispheric relevance, Geology, 40, 891-894, 2012.

Stanley, D. J. and Warne, A. G.: Worldwide Initiation of Holocene Marine Deltas by Deceleration of Sea-Level Rise, Science, 265, 228-231, 1994.

Stuiver, M. and Reimer, P. J.: Extended 14C database and revised CALIB radiocarbon calibration program, Radiocarbon, 35, 215230, 1993.

Stuiver, M., Reimer, P. J., Bard, E., Beck, J. W., Burr, G. S., Hughen, K. A., Kromer, B., McCormac, G., van der Plicht, J., and Spurk, M.: INTCAL98 radiocarbon age calibration, 24,000-0 cal BP, Radiocarbon, 40, 1041-1083 2006.

Swindles, G. T., Plunkett, G., and Roe, H. M.: A delayed climatic response to solar forcing at $2800 \mathrm{cal}$. BP: multiproxy evidence from three Irish peatlands, Holocene, 17, 177-182, 2007.
Thornes, J., Lopéz-Bermùdez, F., and Woodward, J.: Hydrology, river regimes and sediment yield, in: The physical geography of the Mediterranean, edited by: Woodward, J., Oxford University Press, Oxford, 2009.

Tornqvist, T. E. and Hijma, M. P.: Links between early Holocene ice-sheet decay, sea-level rise and abrupt climate change, Nat. Geosci., 5, 601-606, 2012.

Trigo, I. F., Davies, T. D., and Bigg, G. R.: Decline in Mediterranean rainfall caused by weakening of Mediterranean cyclones, Geophys. Res. Lett., 27, 2913-2916, 2000.

Ullman, D. J., Carlson, A. E., Anslow, F. S., LeGrande, A. N., and Licciardi, J. M.: Laurentide ice-sheet instability during the last deglaciation, Nat. Geosci., 8, 534-537, 2015.

Ulses, C., Estournel, C., Durrieu de Madron, X., and Palanques, A.: Suspended sediment transport in the Gulf of Lions (NW Mediterranean): Impact of extreme storms and floods, Cont. Shelf Res., 28, 2048-2070, 2008.

van der Leeuw, S. E.: Climate, hydrology, land use, and environmental degradation in the lower Rhone Valley during the Roman period, C. R. Geosci., 337, 9-27, 2005.

Vella, C. and Provansal, M.: Relative sea-level rise and neotectonic events during the last $6500 \mathrm{yr}$ on the southern eastern Rhône delta, France, Mar. Geol., 170, 27-39, 2000.

Walker, M. J. C., Berkelhammer, M., Björck, S., Cwynar, L. C., Fisher, D. A., Long, A. J., Lowe, J. J., Newnham, R. M., Rasmussen, S. O., and Weiss, H.: Formal subdivision of the Holocene Series/Epoch: a Discussion Paper by a Working Group of INTIMATE (Integration of ice-core, marine and terrestrial records) and the Subcommission on Quaternary Stratigraphy (International Commission on Stratigraphy), J. Quaternary Sci., 27, 649-659, 2012.

Wanner, H., Beer, J., Bütikofer, J., Crowley, T. J., Cubasch, U., Flückiger, J., Goosse, H., Grosjean, M., Joos, F., Kaplan, J. O., Küttel, M., Müller, S. A., Prentice, I. C., Solomina, O., Stocker, T. F., Tarasov, P., Wagner, M., and Widmann, M.: Mid- to Late Holocene climate change: an overview, Quaternary Sci. Rev., 27, 1791-1828, 2008.

Wanner, H., Solomina, O., Grosjean, M., Ritz, S. P., and Jetel, M.: Structure and origin of Holocene cold events, Quaternary Sci Rev., 30, 3109-3123, 2011.

Wanner, H., Mercolli, L., Grosjean, M., and Ritz, S. P.: Holocene climate variability and change; a data-based review, J. Geol. Soc., 172, 254-263, doi:10.1144/jgs2013-101, 2014.

Weaver, C. E.: Potassium, illite and the ocean, Geochim. Cosmochim. Ac., 31, 2181-2196, 1967.

Weiss, B.: The decline of Late Bronze Age civilization as a possible response to climatic change, Climatic Change, 4, 173-198, 1982.

Wirth, S. B., Glur, L., Gilli, A., and Anselmetti, F. S.: Holocene flood frequency across the Central Alps - solar forcing and evidence for variations in North Atlantic atmospheric circulation, Quaternary Sci. Rev., 80, 112-128, 2013. 